\title{
Pengembangan Permainan Halmakimia sebagai Media Pembelajaran Pada Materi Konfigurasi Elektron Kelas X MA/SMA
}

\section{Development of Halmakimia Game as Learning Media on Class X MA/High School Electron Configuration Material}

\author{
Kurniati $^{*}$ \\ ${ }^{1}$ Madrasah Aliyah Negeri 2 Bukittinggi, \\ Jalan Panorama Baru, Bukittinggi, Sumatera Barat, Indonesia 26123 \\ *kurniatriza15@gmail.com
}

\section{ARTICLE INFO}

Received 23 January 2020

Revised 02 February 2020

Published 06 February 2020

\begin{abstract}
This research aims to create and develop a game called halmakimia which can be used as a learning medium in the electron configuration material for class X MA/ $S M A$. This study uses the type of Research and Development $(R \& D)$ with the $4 D$ model. This model has 4 stages of research namely define, design, development, and disseminate. This study conducted a validity test and practicality test from the development stage. Halmakimia learning media is validated by 3 validators from the MAN 2 Bukittinggi chemistry teacher. The practicality questionnaire was filled by 33 student class X MAN 2 Bukittinggi and 2 chemistry teachers MAN 2 Bukittinggi. The results showed the validity test was 0.85 categorized very high. The kappa moment of 33 students MAN 2 Bukittinggi was 0.7 in the high practicality category, and MAN 2 Bukittinggi teachers were 0.83 in the very high category.
\end{abstract}

\section{KEYWORDS}

Halmakimia, Electron Configuration, Learning Media

\begin{abstract}
ABSTRAK
Penelitian ini bertujuan untuk mengembangkan sebuah permainan yang disebut dengan halmakimia yang dapat digunakan sebagai media pembelajaran pada materi konfigurasi elektron kelas X MA/SMA. Penelitian ini menggunakan tipe Research and Development (R\&D) dengan model 4D. Model ini memiliki 4 tahap penelitian yaitu define, design, development dan disseminate. Penelitian ini dilakukan uji validitas dan uji praktikalitas dari tahap pengembangan. Media pembelajaran halmakimia divalidasi oleh 3 orang validator dari guru kimia MAN 2 Bukittinggi. Angket praktikalitas diisi oleh 33 orang peserta didik kelas X MAN 2 Bukittinggi dan 2 orang guru kimia MAN 2 Bukittinggi. Hasil penelitian menunjukkan uji validitas adalah 0.85 dikategorikan sangat tinggi. Momen kappa dari 33 orang peserta didik MAN 2 Bukittinggi adalah 0.7 kategori praktikalitas tinggi, dan guru MAN 2 Bukittinggi 0,83 dengan kategori sangat tinggi.
\end{abstract}

KATA KUNCI

Halmakimia, Konfigurasi Elektron, Media Pembelajaran 


\section{PENDAHULUAN}

Pembelajaran adalah salah satu bentuk implementasi dari suatu kurikulum di sekolah baik tingkat dasar maupun di tingkat menengah. Kurikulum yang dirancang menuntut aktivitas dan kreativitas guru dan peserta didik sesuai dengan rencana yang telah diprogramkan secara efektif. Pembelajaran harus mampu menciptakan suasana pembelajaran partisipatif, aktif, kreatif dan menyenangkan supaya kompetensi inti dan kompetensi dasar yang telah dirancang dapat terlaksana ${ }^{[1]}$.

Suatu pembelajaran pada dasarnya tidak hanya mempelajari tentang konsep, teori dan fakta akan tetapi juga aplikasi dalam kehidupan sehari-hari, dengan demikian materi pembelajaran tidak hanya tersusun atas hal-hal sederhana yang bersifat hafalan dan pemahaman, tetapi juga tersusun atas materi yang kompleks yang memerlukan analisis, aplikasi dan sintesis, untuk itu guru harus bijaksana menciptakan situasi dan kondisi kelas yang kondusif agar proses belajar mengajar dapat berlangsung sesuai dengan tujuan yang diharapkan ${ }^{[2]}$. Berdasarkan alasan tersebut, maka sangatlah penting bagi para pendidik memahami karakteristik materi, peserta didik dan metodologi pembelajaran dalam proses pembelajaran terutama yang berkaitan dengan pemilihan metode, model, dan media yang dibutuhkan dalam pembelajaran.

Konfigurasi elektron merupakan salah satu materi pelajaran yang dipelajari oleh peserta didik kelas $\mathrm{X}$ semester 1 yang terdapat dalam kurikulum kimia SMA/MA 2013 edisi revisi 2018. Materi ini merupakan materi faktual, konseptual dan prosedural. Berdasarkan karakteristik materi tersebut diperlukan pengetahuan tentang konfigurasi elektron, maka diharapkan peserta didik lebih banyak membaca, berdiskusi bahkan diharapkan Peserta didik lebih banyak berlatih agar tercapainya indikator pencapaian kompetensi (IPK) yang diharapkan sesuai dengan kurikulum 2013 edisi revisi $2018^{[3]}$.

Materi konfigurasi elektron biasanya diajarkan dengan menggunakan modul, buku teks, power point dan lembar kerja peserta didik (LKPD). Pemberian latihan untuk Peserta didik juga menggunakan modul, buku teks dan lembaran kerja peserta didik (LKPD). Ditinjau dari karakteristik peserta didik dan hasil wawancara dengan 2 orang guru kimia, diperoleh informasi bahwa aktivitas peserta didik masih rendah dan lebih cenderung bersifat individual, kurang kerja sama dan tidak kompetitif. Demikian juga dengan perolehan hasil belajar peserta didik pada materi konfigurasi elektron setelah diberikan tes, ternyata juga kurang memuaskan.

Dengan kenyataan yang didapatkan di lapangan, maka dibutuhkan suatu inovasi dalam pembelajaran. Inovasi dalam pembelajaran bertujuan menciptakan pembelajaran yang bervariasi diantaranya pembuatan media pembelajaran yang sesuai dengan karakteristik materi pelajaran. Sudjana dan Rivai (1992:2) dalam Arsyad ${ }^{[4]}$ menyatakan Media pembelajaran diharapkan dapat menarik perhatian peserta didik dalam memahami konsep pelajaran sehingga dapat menumbuhkan motivasi dalam belajar, bahan pembelajaran akan lebih jelas maknanya, metode belajar akan lebih bervariasi dan juga merangsang peserta didik untuk lebih aktif berlatih dengan baik dan bersungguh-sungguh.

Salah satu bentuk media yang sesuai dengan manfaat media diantaranya adalah media untuk pembelajaran yang berupa game atau permainan. Permainan dapat membuat peserta didik aktif dalam pembelajaran, muncul rasa ingin tahu, rasa bergembira dan rasa berkompetisi di antara peserta didik dan dapat menambah motivasi peserta didik dalam belajar ${ }^{[5]}$. Sesuai dengan tujuan media pembelajaran dalam bentuk permainan yang dinyatakan di atas, maka dibuatlah media pembelajaran dalam bentuk permainan (game) yang dinamakan dengan Halmakimia. Permainan pembelajaran Halmakimia merupakan salah satu media pembelajaran yang dapat digunakan dalam pembelajaran konfigurasi elektron yang diharapkan dapat menarik perhatian peserta didik dalam belajar. Halmakimia adalah permainan tradisional yang biasa dimainkan oleh anakanak dengan anggota permainan 2 sampai 5 orang. Permainan ini menggunakan papan halma, 1 buah dadu dan anak halma. Permainan dimainkan secara bergiliran sesuai dengan kesepakatan anggota dalam permainan tersebut. Permainan halma ini kemudian di modifikasi sesuai dengan materi pembelajaran yang akan dipelajari oleh peserta didik. Untuk pembelajaran konfigurasi elektron permainan halma ini dimodifikasi sesuai dengan materi pembelajaran konfigurasi elektron. Permainan halma ini dimodifikasi, dimana alur permainannya menggunakan dan menerapkan konsep pengisian elektron berdasarkan tingkat energi yang dikemukakan oleh Aufbau, tetapi aturan permainannya memanfaatkan model permainan halma.

Permainan Halmakimia dirancang sedemikian rupa yang berisikan konsep-konsep dan soal latihan yang bertujuan untuk memantapkan konsep peserta didik mengenai konfigurasi elektron. Berdasarkan hasil wawancara dengan beberapa orang peserta didik, bahwa permainan Halmakimia dapat menarik minat Peserta didik karena dalam permainan ini seluruh Peserta didik terlibat aktif dalam proses pembelajaran. Pembelajaran metode ini lebih efektif karena dapat menciptakan suasana belajar yang menyenangkan dan lebih bersemangat belajar dalam kelompok kecil serta dapat berkompetisi antara peserta didik. Setelah pembelajaran peserta didik dapat memantapkan konsep-konsep yang sudah dipelajari dengan latihan-latihan tentang materi yang telah dipelajari sehingga peserta didik memperoleh keterampilan baru. 
Permainan Halmakimia yang akan dimodifikasi dengan mengambil gambaran umum dari jari-jari atom dalam suatu atom, jari-jari atom terdiri 7 lintasan, dimulai dari lintasan 1 sampai ke lintasan ke 7. Pada masing-masing lintasan dibatasi oleh ruang kebolehjadian untuk menentukan elektron yang disebut dengan orbital. Orbital yang digunakan tergantung dari lintasan dimana tempat orbital tersebut ${ }^{[6]}$. Peserta didik dapat berlatih menggunakan Halmakimia untuk memantapkan konsep konfigurasi elektron sebagai media pembelajaran alternatif yang biasanya hanya menggunakan modul, buku teks dan lembar kerja peserta didik (LKPD).

Berdasarkan uraian di atas, dilakukan penelitian pengembangan permainan Halmakimia pada materi pembelajaran konfigurasi elektron. Media ini diharapkan dapat membuat siswa lebih aktif dalam pembelajaran serta dapat mengurangi ketengan peserta didik dalam lingkungan belajar. Sehingga dengan menggunakan media pembelajaran Halmakimia diharapkan dapat meningkatkan aktivitas dan hasil belajar peserta didik. Penelitian ini bertujuan untuk mengembangkan permainan Halmakimia dan menguji tingkat validitas dan tingkat praktikalitas media yang telah dikembangkan.

\section{METODE}

Jenis penelitian yang digunakan pada penelitian ini adalah research and development (R\&D). Metode ini merupakan metode penelitian untuk menghasilkan suatu produk berupa permainan Halmakimia sebagai media pembelajaran alternatif yang valid dan praktis untuk digunakan dalam pembelajaran guna meningkatkan aktivitas belajar dalam menanamkan konsep konfigurasi elektron serta dapat meningkatkan hasil belajar, serta menguji keefektifan produk yang digunakan. Penelitian ini dilakukan di MAN 2 Bukittinggi. Subjek penelitian adalah guru MAN 2 Bukittinggi dan 33 orang peserta didik kelas $\mathrm{X}$ MIA 3 MAN 2 Bukittinggi.

Penelitian permainan Halmakimia ini dikembangkan dengan model pengembangan 4-D yang dikembangkan oleh Thiagarajan dan Sammel. Model penelitian ini terdiri dari 4 tahapan yaitu tahap define (pendefinisian), tahap design (perancangan), tahap development (pengembangan) dan tahap disseminate (penyebaran) ${ }^{[7]}$.

Tahap define (pendefinisian) bertujuan untuk menetapkan dan mendefinisikan syarat-syarat pembelajaran yang dibagi dalam 5 langkah yaitu (1) analisis materi pembelajaran, (2) analisis KI dan KD materi konfigurasi elektron sesuai dengan kurikulum 2013 revisi 2018, (3) dijabarkan dalam bentuk indikator pencapaian kompetensi (IPK), (4) analisis konsep dilakukan dengan mengidentifikasi, menganalisis dan menyusun konsep-konsep apa saja yang dipelajari pada materi konfigurasi elektron sesuai dengan tuntutan kurikulum 2013 edisi revisi 2018. Hasil analisis konsep dirumuskan tujuan, (5) perumusan tujuan di dasarkan pada kompetensi dasar yang terdapat dalam kurikulum 2013 edisi revisi 2018.

Tahap design (perancangan) merupakan tahap perancangan media yang relevan dengan data yang telah diperoleh. Tahap development (pengembangan) ini memiliki tujuan untuk menghasilkan produk akhir berupa media permainan Halmakimia Pada tahap pengembangan ini lakukan uji validitas media yang dikembangkan. Uji validitas media dilakukan oleh 3 orang guru kimia. Uji validitas media merupakan penilaian terhadap rancangan media berdasarkan fungsi media yaitu fungsi atensi, fungsi kognitif, fungsi afektif dan fungsi kompensatoris ${ }^{[4]}$. Uji praktikalitas media dilakukan oleh dua orang orang guru kimia dan 33 orang peserta didik. Uji praktikalitas media berdasarkan pada karakteristik media praktis yaitu kemudahan penggunaan, efisiensi waktu dan manfaat.

Instrumen yang digunakan dalam penelitian ini adalah angket validitas dan angket praktikalitas media. Data yang diperoleh dari angket selanjutnya dianalisis menggunakan formula kappa cohen dimana pada akhir pengolahan diperoleh momen kappa $(\mathrm{k})^{[8]}$.

$$
\text { momen kappa }(k)=\frac{\rho_{0}-\rho_{e}}{1-\rho_{e}}
$$

$\rho_{0}$ adalah proporsi yang tidak terealisasi

$\rho_{e}$ adalah proporsi yang terealisasi

Momen kappa $(k)$ berkisar dari 0 sampai 1 dengan interpretasi disajikan pada Tabel 1 .

Tabel 1. Interpretasi nilai momen kappa.

\begin{tabular}{c|c} 
Interval & Kategori \\
\hline$<0,00$ & Tidak \\
\hline $0,01-0,20$ & Sangat rendah \\
\hline $0,21-0,40$ & Rendah \\
\hline $0,41-0,60$ & Sedang \\
\hline $0,61-0,80$ & Tinggi \\
\hline $0,81-1,00$ & Sangat tinggi
\end{tabular}

\section{HASIL DAN DISKUSI}

\subsection{Hasil}

\subsubsection{Tahap Define (Pendefinisian)}

Materi pembelajaran konfigurasi elektron di kelas XSMA/MAdilaksanakan dengan menggunakan media berupa buku teks, modul dan power point dan lembar kerja peserta didik (LKPD). Berdasarkan hasil diskusi dengan guru-guru Kimia SMA/MA kelas $\mathrm{X}$ di Bukittinggi bahwa media pembelajaran yang sudah digunakan sebelumnya dalam pembelajaran tentang konfigurasi elektron ini dirasakan kurang 
maksimal dalam meningkatkan minat, kerjasama, kompetisi serta aktivitas belajar peserta didik secara optimal. Berdasarkan interview dengan peserta didik bahwa Pengunaan modul, buku teks dan lembar kerja peserta didik (LKPD) membuat suasana belajar kurang bervariasi, kadang-kadang membuat Peserta didik jenuh sehingga diperlukan suatu media pembelajaran alternatif yang dapat membuat suasana pembelajaran yang lebih menyenangkan dan menantang, salah satu bentuknya adalah game (permainan).

Tujuan pembelajaran pada materi konfigurasi elektron dengan merinci isi materi ajar secara garis besar. Analisis tugas pada materi konfigurasi elektron yang sesuai dengan kurikulum 2013 edisi revisi 2018 adalah berupa analisis Kompetensi Inti (KI) dan analisis kompetensi dasar (KD) yang dijabarkan menjadi beberapa indikator pencapaian kompetensi (IPK). Pada Materi konfigurasi elektron $\mathrm{KD}$ yang harus dipenuhi adalah KD 3.3 yang berbunyi Menganalisis struktur atom berdasarkan teori atom Bohr dan teori mekanika kuantum yang dikembangkan menjadi indikator pencapaian kompetensi 3.3.3 yaitu Menjelaskan Konfigurasi elektron dari beberapa unsur berdasarkan teori mekanika kuantum.

Analisis konsep merupakan identifikasi, merinci dan menyusun secara sistematis konsepkonsep utama pada materi konfigurasi elektron, Konsep utama dari konfigurasi elektron adalah aturan Aufbau yaitu aturan yang mengatur bahwa pengisian elektron pada suatu atom. Aturan Aufbau berbunyi "Elektron-elektron dalam suatu atom berusaha untuk menempati subkulit-subkulit yang berenergi rendah, kemudian baru ke tingkat energi yang lebih tinggi".

Analisis tujuan pembelajaran berdasarkan indikator pencapaian kompetensi yang telah dirumuskan, adapun tujuan dalam perancangan media pembelajaran Halmakimia adalah melalui pembelajaran Halmakimia pada pembelajaran konfigurasi elektron diharapkan peserta didik terlibat aktif dalam proses belajar mengajar berlangsung, memiliki rasa ingin tahu, kerja sama, teliti, berpikir kritis dan jujur dalam melakukan pengamatan serta bertanggung jawab dalam mengemukakan pendapat, menjawab pertanyaan saran maupun kritik. Dalam menanamkan konsep konfigurasi elektron.

\subsubsection{Tahap design (Perancangan)}

Tahap design bertujuan untuk merancang media pembelajaran kimia dalam bentuk Halmakimia pada materi pembelajaran konfigurasi elektron. Perangkat pembelajaran dikumpulkan dalam suatu kotak. Set permainan terdiri dari papan permainan, aturan permainan, tabel periodik, gelas pengocok dadu, dadu, anak halma dan form penilaian. Prototipe dari alat yang dikembangkan dapat dilihat dari Gambar 1, Gambar 2, Gambar 3 dan Gambar 4.

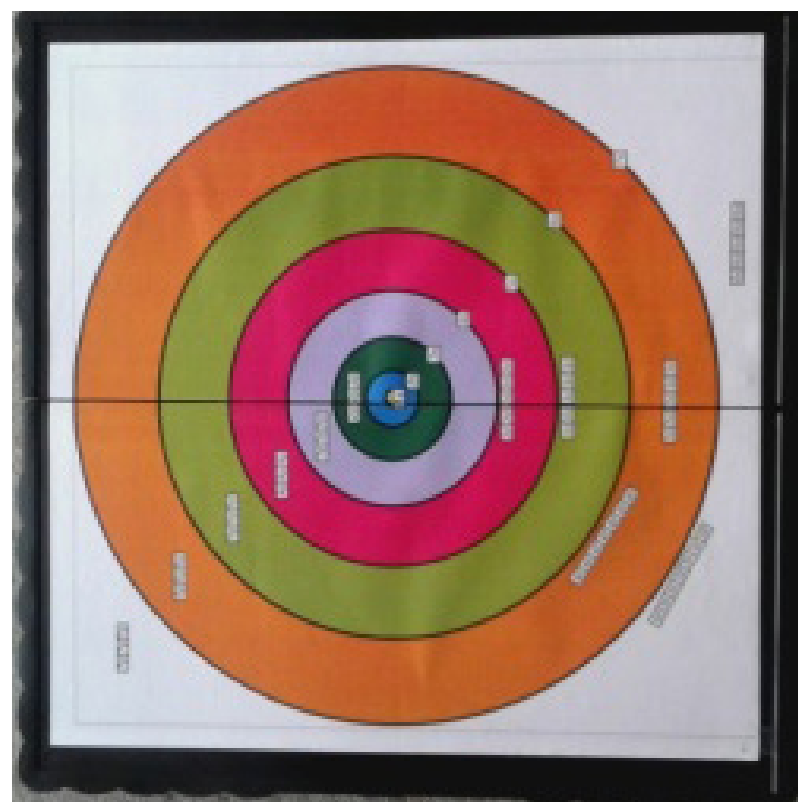

Gambar 1. Desain papan Halmakimia

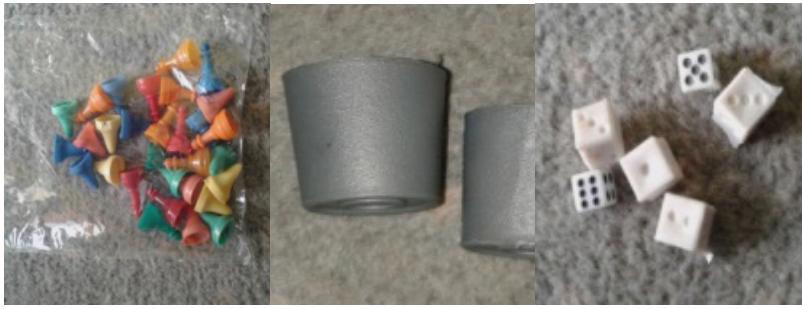

Gambar 2. Anak halma, pengocok dadu dan dadu

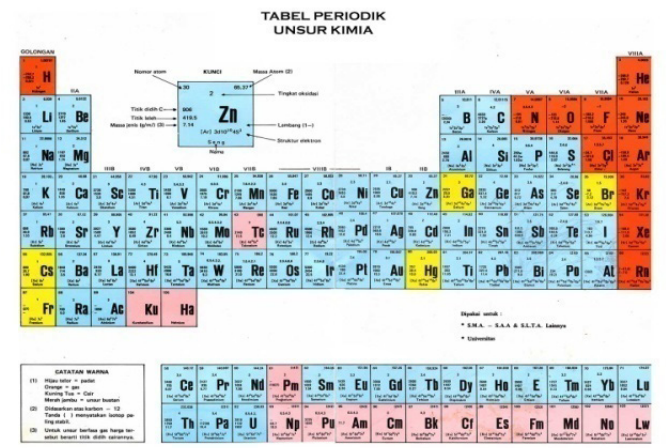

Gambar 3. Tabel periodik

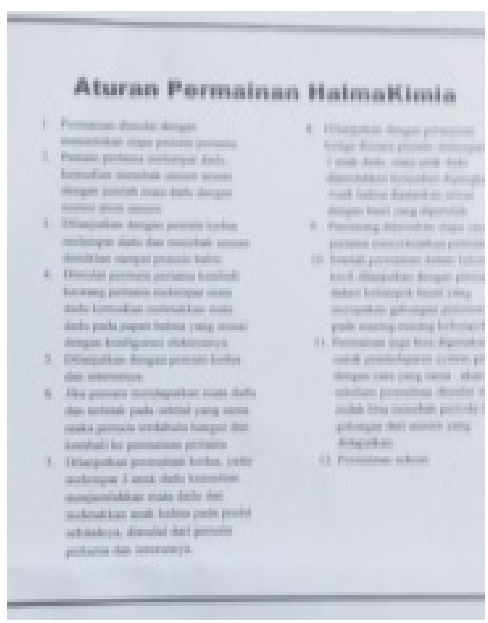

Gambar 4. Aturan Permainan Halmakimia 


\begin{tabular}{|c|c|c|c|c|c|c|c|}
\hline No & Nama & $\begin{array}{l}\text { Tebak } \\
\text { Unsur }\end{array}$ & $\begin{array}{c}\text { Periode } \\
\text { \&gol }\end{array}$ & Game 1 & Game 2 & Game 3 & Juara \\
\hline 1 & A & & & & & & \\
\hline 2 & B & & & & & & \\
\hline 3 & $\mathrm{C}$ & & & & & & \\
\hline 4 & D & & & & & & \\
\hline 5 & E & & & & & & \\
\hline
\end{tabular}

Gambar 5. Tabel penilaian pada permainan Halmakimia

\subsubsection{Tahap Development}

Tahap ini bertujuan untuk menghasilkan media pembelajaran yang telah direvisi berdasarkan masukan dari beberapa pihak. Uji Validitas dilakukan oleh 2 orang guru kimia senior. Validasi media ini didasarkan pada empat fungsi media yaitu fungsi atensi, fungsi afektif, fungsi kognitif dan fungsi kompensatoris ${ }^{[4]}$. Hasil validasi media permainan Halmakimia menunjukkan kategori validasi tinggi dengan momen kappa sebesar 0,85 Artinya media pembelajaran Halmakimia pada materi konfigurasi elektron sudah memenuhi fungsi sebagai media pembelajaran. Untuk uji praktikalitas media didasarkan pada kepraktisannya suatu media untuk digunakan dalam pembelajaran. Indikator yang digunakan dalam uji praktikalitas adalah kemudahan penggunaannya, efisiensi waktu dan manfaat. Uji praktikalitas media dilakukan terhadap 2 orang guru kimia MAN 2 Bukittinggi dan 33 orang peserta didik kelas X MIA 3 MAN 2 Bukittinggi.

Uji praktikalitas media pembelajaran Halmakimia oleh 3 orang guru kimia MAN 2 Bukittinggi menunjukkan tingkat praktikalitas sangat tinggi dengan momen kappa (k) sebesar 0,83 sedangkan uji praktikalitas media permainan Halmakimia oleh 33 orang peserta didik kelas X MIA 3 MAN 2 Bukittinggi menunjukkan tingkat media dengan kategori tinggi, dimana memiliki momen kappa (k) sebesar 0.7.

\subsubsection{Tahap disseminate}

Tahap ini bertujuan untuk menyebarkan dan mensosialisasikan media pembelajaran Halmakimia pada pembelajaran konfigurasi elektron kimia kelas $\mathrm{X}$ semester satu sesuai dengan kurikulum 2013 edisi revisi 2018 kepada guru-guru MAN 2 Bukittinggi secara umum dan guru-guru kimia secara khusus.

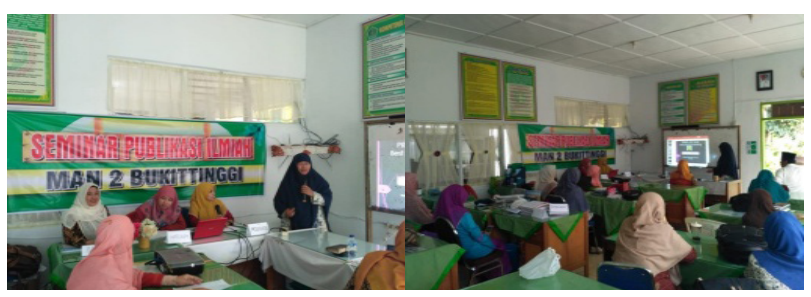

Gambar 6. Disseminasi Halmakimia di depan guru MAN 2 Bukittinggi dan guru-guru di lingkungan Kementerian Agama kota Bukittinggi dan Agam.

\subsection{Diskusi}

Permainan Halmakimia merupakan media pembelajaran yang telah dikembangkan untuk materi konfigurasi elektron pada mata pelajaran kimia kelas X semester 1 sesuai dengan kurikulum 2013 edisi revisi 2018. Permainan Halmakimia sudah di uji Validitas dan praktikalitas.

\subsubsection{Uji Validitas}

Media pembelajaran dapat dikatakan valid jika telah memenuhi fungsi dari media tersebut, dimana terdapat 4 fungsi media pembelajaran, khususnya media visual yaitu fungsi atensi, fungsi afektif, fungsi kognitif, dan fungsi kompensatoris ${ }^{[4]}$. Uji validitas dilakukan dengan pengisian angket validasi oleh beberapa orang pakar, yang merupakan orang yang profesional di bidangnya atau orang yang dianggap mengerti dengan maksud dan substansi pemberian media $^{[6]}$ Uji validitas media permainan Halmakimia yang dikembangkan dalam penelitian ini dilakukan oleh tiga orang guru kimia. Hasil uji validitas media Halmakimia oleh validator berdasarkan keempat fungsi media di atas dapat dilihat pada Gambar 7.

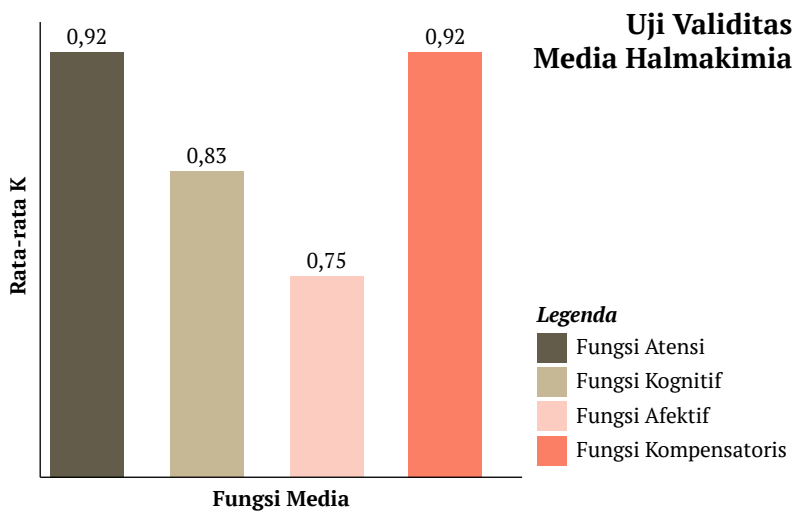

Gambar 7. Hasil uji validitas

Berdasarkan Gambar 7 dapat dilihat bahwa fungsi atensi dan fungsi kompensatoris dari Halmakimia yang dikembangkan memiliki nilai momen kappa paling tinggi. Menurut Levie \& Lentz dalam Arsyad (2013), fungsi atensi media visual merupakan inti yaitu menarik dan mengarahkan perhatian Peserta didik untuk berkonsentrasi kepada isi pelajaran yang berkaitan dengan makna visual yang ditampilkan atau menyertai teks materi pelajaran. Seringkali pada awal pelajaran Peserta didik tidak tertarik dengan materi pelajaran atau mata pelajaran itu merupakan salah satu pelajaran yang tidak disenangi oleh mereka sehingga mereka tidak memperhatikan pelajaran. Hal ini dapat dilihat bahwa permainan Halmakimia dapat membuat Peserta didik tertarik untuk belajar dan mengarahkan konsentrasinya untuk memahami isi pelajaran tentang konfigurasi elektron.

Sedangkan fungsi kompensatoris media Halmakimia memberikan konteks untuk memahami teks membantu Peserta didik yang lemah dalam membaca untuk mengorganisasikan informasi dalam teks dan mengingatnya kembali. Dengan kata lain media pembelajaran Halmakimia berfungsi 
untuk mengakomodasikan Peserta didik yang lemah dan lambat menerima dan memahami isi pelajaran yang disajikan dengan teks atau disajikan secara verbal. Hal ini dapat dilihat dengan bagaimana Peserta didik yang lemah dalam memahami dan mengorganisasikan informasi dalam teks dapat mengingatkan kembali, sehingga media ini efektif dalam pembelajaran. Selain itu, pada kategori lain juga menunjukkan hasil yang tinggi, dimana untuk keseluruhan kategori pada uji validitas ini memiliki momen kappa rata-rata 0,85 dengan kategori validitas sangat tinggi. Artinya, media Halmakimia ini sudah valid dan memenuhi syarat sebagai media pembelajaran.

\subsubsection{Uji Praktikalitas}

Uji praktikalitas dimaksudkan untuk mengetahui kepraktisan penggunaan suatu media. Suatu media dapat dikatakan praktis jika media tersebut dapat memudahkan penggunanya (guru dan Peserta didik) untuk mencapai tujuan dalam pembelajaran. Uji praktikalitas ini dilakukan menggunakan beberapa indikator kepraktisan media, yaitu kemudahan penggunaan, efisiensi waktu, dan manfaat media yang dikembangkan. Uji praktikalitas ini dilakukan terhadap guru dan Peserta didik. Hasil uji praktikalitas ini dapat dilihat pada Gambar 8.

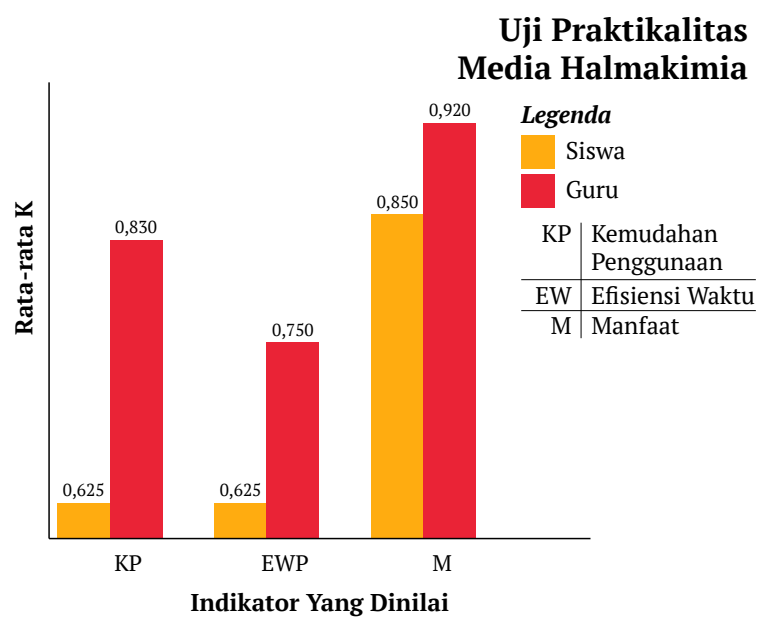

Gambar 8. Hasil uji praktikalitas Halmakimia

Berdasarkan gambar di atas dapat dilihat bahwa media Halmakimia yang dikembangkan sudah menunjukkan angka yang bagus. Uji praktikalitas media oleh guru memiliki momen kappa rata-rata 0,83 dengan kategori tingkat praktikalitas sangat tinggi dan uji praktikalitas oleh Peserta didik memiliki momen kappa rata-rata 0,70 dengan kategori tinggi. Jadi, secara keseluruhan media permainan Halmakimia yang dikembangkan ini praktis untuk digunakan. Meskipun begitu, diantara tiga kategori yang digunakan dalam uji praktikalitas media ini, kategori efisiensi waktu dan kemudahan menggunakan media memiliki momen kappa yang sama lebih rendah dari kategori Manfaat. Hal ini dikarenakan masih banyak peserta didik yang belum terlalu memahami bagaimana cara menggunakan permainan ini sehingga memakan waktu yang lebih lama. Namun, hal ini bukanlah menjadi sebuah masalah besar karena media pembelajaran berupa permainan bisa digunakan dimana saja, baik pada saat pembelajaran di dalam kelas maupun di luar kelas, sehingga Peserta didik memiliki lebih banyak waktu untuk bermain.

Beberapa keunggulan media permainan khususnya Halmakimia ini setelah di uji coba kepada peserta didik ternyata dapat meningkatkan minat belajar dan jiwa kompetisi Peserta didik, mudah digunakan dimana saja, membutuhkan strategi bermain sehingga peserta didik juga dituntut untuk pandai menggunakan peluang yang ada, serta bisa digunakan berulang-ulang. Namun, media permainan Halmakimia pada materi konfigurasi elektron yang telah dikembangkan ini penelitian research \& development (R\&D) dengan model 4-D yang terdiri dari tahap define, design, develop, dan disseminate belum diuji efektivitasnya. Untuk menentukan efektivitas media ini perlu dilakukan penelitian yang lebih lanjut.

\section{SIMPULAN}

Penelitian pengembangan permainan Halmakimia sebagai media pembelajaran pada materi konfigurasi elektron dapat dilakukan menggunakan jenis Permainan Halmakimia yang telah dikembangkan pada penelitian ini memiliki tingkat validitas sangat tinggi. Permainan ini juga memiliki tingkat praktikalitas tinggi berdasarkan uji oleh Peserta didik dan tingkat praktikalitas sangat tinggi berdasarkan uji praktikalitas oleh guru.

\section{REFERENSI}

1. Mahfudz A. Cara Cerdas Mendidik yang Menyenangkan: Berbasis Super Ouantum Teaching. 1 ed. Bandung: Simbiosa Rekatama Media; 2012.

2. Trianto. Mendesain Model Pembelajaran Inovatif-Progresif. Jakarta: Kencana Prenada Media Group; 2012.

3. Depdiknas. Panduan Pengembangan Silabus Mata Pelajaran Kimia. Jakarta: Ditjen Manajemen Pendidikan Dasar dan Menengah; 2018.

4. Azhar A. Media Pembelajaran. Depok: PT. Rajagrafindo Persada; 2013.

5. Yolanda NS, Iswendi. Pengembangan Ludo Kimia sebagai Media Pembelajaran pada Materi Bentuk Molekul Kelas X SMA/MA. Edukimia 2019;1(3):9.

6. Sentot I. Kimia Berbasis Eksperimen untuk Kelas X SMA/MA. PT. Tiga S. Solo: 2013.

7. Trianto. Model Pembelajaran Terpadu. Jakarta: Bumi Aksara; 2012.

8. Fadlah RY, Bayharti. Pengembangan Permainan Scrabble Kimia sebagai Media Pembelajaran pada Materi Minyak Bumi Kelas XI SMA. Edukimia 2019;1(3). 